This is a self-archived version of an original article. This version may differ from the original in pagination and typographic details.

Author(s): Sihto, Tiina

Title: Distances and proximities of care : Analysing emotio-spatial distances in informal caring

Year: 2018

Version: Accepted version (Final draft)

Copyright: @ 2018 Elsevier Ltd.

Rights: $C C B Y-N C-N D 4.0$

Rights url: https://creativecommons.org/licenses/by-nc-nd/4.0/

Please cite the original version:

Sihto, T. (2018). Distances and proximities of care : Analysing emotio-spatial distances in informal caring. Emotion, Space and Society, 29, 62-68.

https://doi.org/10.1016/j.emospa.2018.10.002 
Distances and proximities of care: Analysing emotio-spatial distances in informal caring

\section{Distances and proximities of care: Analysing emotio-spatial distances in informal caring}

Abstract: This article analyses how emotio-spatial distances in informal caring are experienced by Finnish women who are employed and simultaneously caring for an ageing relative. The article's research questions are: how do spatial distance and proximity shape informal carers' emotional responses to caring? What kinds of emotion do spatial 'distance' or 'proximity' evoke in the interview accounts of informal carers? The article draws on theorisations regarding emotional geographies of care. The data consists of two focus group interviews with a total of 12 women who were combining employment with caring. The analysis shows that spatially proximate carers have difficulty detaching from caring, whereas spatially distant carers experience feelings of worry and insecurity regarding the well-being of their care partner. However, in some cases spatial distance also functions as a way for carers to set limits on the amount and intensity of care. The article illustrates the complex ways emotions enter and shape caringscapes, i.e. the spatio-temporal frameworks of care. The analysis also highlights gendered dynamics both among (potential) carers and in care partnerships, and how these dynamics are reflected across varying distances.

Keywords: Emotional geographies, focus groups, informal care 
Distances and proximities of care: Analysing emotio-spatial distances in informal caring

\section{Introduction}

In recent decades, the 'landscapes of care' (Milligan \& Wiles, 2010) have become increasingly complex. Increased mobility has meant longer distances between family members, and caring for one's ageing relatives from a distance has become an important issue for many geographically mobile families (Phillips \& Bernard, 2010; Baldassar, 2007, 2008). At the same time as these changes are taking place in families, the overall societal framework of care provision is being transformed. Currently the availability of formal care is decreasing, while the need for care is growing due to the Western world's ageing population. This has led many European welfare states to strengthen the role of family members in providing care (Frericks et al., 2014).

These developments are also taking place in Nordic countries, which have traditionally been known for their comprehensive care policies (Meagher \& Szebehely, 2013). In Finland, where tax-funded service provision and access to universal social care services have been fairly strong, there has been a shift from public to greater private responsibility, increasing both the marketisation of care services (ibid.) and the expectation that family members will provide care for their ageing relatives (Jolanki et al., 2013). Due to reductions in the coverage of homebased care services, a large percentage of older people have been excluded from such services, thereby increasing their reliance on informal care; only those with the greatest need have access to formal care (Kröger \& Leinonen, 2012).

Caring continues to be a deeply gendered issue. Even though gender roles and gendered expectations of women and men are being constantly reshaped, women are still more often seen as 'natural' carers than men, thus facing greater expectations to care. Working-age women with caring responsibilities face two contrasting cultural expectations: to be devoted carers and committed workers at the same time (Jolanki, 2015). Working carers can face significant 
Distances and proximities of care: Analysing emotio-spatial distances in informal caring

constraints regarding their employment possibilities, since both work and care often demand the same kind of intensiveness, flexibility and emotional presence (Kauppinen \& Jolanki, 2012). In Finland, the culture of full-time work continues to be strong. Consequently, working women with caring responsibilities often combine care with full-time work. The everyday lives of these women are further complicated by the fact that Finland is sparsely populated and geographically large. Thus the spatial and temporal settings of working carers' everyday lives, to which McKie et al. (2002) refer as 'caringscapes', can be particularly complex.

This article analyses how Finnish women who are in paid employment and simultaneously caring for an ageing relative experience emotio-spatial distances in informal caring. Emotio-spatial distance refers to the ways emotions and spatiality are intertwined: how emotions can be understood in the context of the places where they are experienced, and how the feeling of place is essential for making sense of our experiences in that particular place (Davidson \& Milligan, 2004). Previous research by Milligan (2005) has emphasised that the emotional experience of caring is intimately bound up with the place of care. In this article, the focus is on emotions regarding the space between care partners, as the interest is in analysing how these 'distances between' shape the emotional dimension of caring.

In this article, following Bryden (2005), the term 'care partnership' is used to conceptualise the dyad between the person with care needs and the person responding to those care needs. The article's research questions are: how do spatial distance and proximity shape informal carers' emotional responses to caring? What kinds of emotion do spatial 'distance' or 'proximity' evoke in the interview accounts of informal carers? In this article, emotions expressed by informal carers are understood as both deeply personal and also shaped in and by the wider sociocultural context (e.g. Ahmed, 2004) and norms regarding care. Conceptually, the article draws on theorisations of emotional geographies, with particular attention to how 
Distances and proximities of care: Analysing emotio-spatial distances in informal caring

emotions are tied to the spatial distance(s) of caring (see Herron \& Skinner, 2013).

\section{Spatial distance and emotions in informal caring}

The comprehensiveness of care is underlined by its classical definition in gender studies: it is a 'labour of love' (Graham, 1983) that involves emotional, mental, physical and cognitive work, engaging mind and body in a range of intertwining practices and thought processes (Lynch, 2007). Caring has been characterised as having two distinctive, yet often inseparable, components: caring for and caring about. Caring for refers to hands-on care (e.g. cooking and cleaning), while caring about refers to the emotional and affective dimensions of care. The division of caring tasks between genders tends to follow the traditional division of household labour (Hequembourg \& Brallier, 2005), with women doing most of the caring for. Hence, care provided by women is often situated at the 'heavy end' of caring (Jegermalm, 2004) and typically requires spatial proximity to the care partner.

In Finland, both care policy and public opinion are in favour of older people having the option to 'age in place' and live in ordinary housing as long as it is considered possible to do so (Ministry of the Environment, 2013), with the support of formal and informal care arrangements. Policies to support ageing in place move care from the formal institutional spaces of hospitals and nursing homes to the informal private sphere of the home (Milligan, 2001), emphasising the role of families and other kin in the caring process. This raises the question of how care is carried out in practice, especially in cases where those who are likely to become carers (e.g. children of ageing parents) live far from the person with care needs. When kin start to divide caring responsibilities, a likely scenario is that the people living closest to the person with care needs will bear the main responsibility for care. Previous research has shown that spatial proximity increases one's overall likelihood of providing care (Brandt et al., 
Distances and proximities of care: Analysing emotio-spatial distances in informal caring

2009) as well as the frequency and intensity of the care provided (Joseph \& Hallman, 1998).

However, the division of care is also shaped by social and structural factors, such as the gender and employment situation of the (potential) carer, and the emotional dynamics between the care partners (Finch \& Mason, 1993).

Caring can be, and often is, inflected with a variety of complex emotions and relational dynamics (Wiles, 2003; Bondi, 2008; Baldassar, 2015). Caring for one's parent can be a source of particularly ambivalent emotions, as it signals a shift in the relational power dynamic between the parent and the adult child (Hillcoat-Nallétamby \& Phillips, 2011). Care connects people, and the everyday doing of care often produces close emotional ties between care partners, whether such ties are desired or not (Evans \& Thomas, 2009; Bondi, 2008). The embodied inner experience of the carer can be at odds with the way the carer interprets and responds to the needs of the care partner, i.e. does the emotion management (Hochschild, 1979) of caring. When the inner experience conflicts with the interpretation of the other's needs, the carer has to weigh up whether to perform actions that are at odds with his or her inner state (Milligan, 2005). Caring can also produce a site where societal norms and expectations clash with the carer's emotions. Caring is not necessarily just 'a labour of love' but can also be (further) spurred by the carer seeing care as an inevitable moral responsibility, or by fear of the social or emotional consequences of choosing not to care (Bowlby et al., 2010). For working carers, their emotions regarding care are further complicated by their choices regarding employment: a previous study by Jolanki (2015) on Finnish women who combine work and care showed that women anticipate moral blame not only if they are seen to be prioritising work over care, but also if they decide to leave work in order to care.

Caring produces subjective geographies that help individuals make sense of their experiences regarding care (Bondi, 2008). Research on emotional geographies of caring has 
Distances and proximities of care: Analysing emotio-spatial distances in informal caring

explored these subjective geographies, and has shown the various ways in which the emotional dimensions of care are tied to the place(s) and space(s) of care and vice versa - how space and place shape the emotional dimension of caring (Milligan, 2005). In studies on emotional geographies, the words 'distance' and 'proximity' refer not only to spatiality, but also to social and emotional closeness and distance, which are often tied to physical distance. Emotional distances and proximities pose their own challenges and ambivalences, and can be liberating or constraining (Phillips \& Bernard, 2010; Milligan \& Wiles, 2010). Emotional bonds can persevere across distances, even though long distances are also part of the reshaping of such bonds (Baldassar, 2007, 2008).

When one is analysing working carers' experiences of emotio-spatial distance, it is also crucial to take account of the temporality of daily life. The concept of 'caringscapes' (McKie et al., 2002) uses a spatio-temporal framework to analyse the experiences of working carers. Caringscapes comprise the interaction of work and care over space and time, and reflect the activities and emotions connected to how people map those routes of caring and working (Bowlby et al., 2010). Caringscapes shift and change through time and space, in response to changing circumstances and demands in carers' lives. The everyday realities of working and caring are shaped by past experiences and future anticipations, as well as by practicalities related to time and space in everyday life, such as the time required to move between the spaces of home, work and care (McKie et al., 2002).

For many working carers, the time and place of work are relatively static, whereas the spaces and times of care are more fluid and prone to change. In carers' daily lives, the spaces of work and care usually remain separate, but the times of work and care demands can overlap (McKie et al., 2002). Even though some parts of caring can be scheduled in advance, the basic principle of caring entails responding to the needs of others as they arise. Care needs can 
Distances and proximities of care: Analysing emotio-spatial distances in informal caring

emerge and change quickly, and can require an immediate response from the person giving care. This can pose significant temporal challenges, especially for those combining fixed working times with fluid care times (cf. ibid.).

\section{Data and methods}

Focus group interviews

The data for this article consists of two semi-structured focus group interviews with working women who have an older relative with care needs. The interviews were carried out as part of the FLOWS research project (FLOWS: Impact of local welfare systems on female labour force participation and social cohesion 2011-2014, European Commission FP7). The interviews were conducted in 2013 in the city of Jyväskylä. Both interviews lasted around three hours and were conducted in Finnish. The interviews were digitally recorded and later transcribed. In both interviews, in addition to the moderator, a note taker was present. Guidelines on research ethics in the conduct of focus groups were provided by the project before the recruitment of interviewees began. Before the interviews started, all of the interviewees were informed about ethical measures such as their right to refuse the research use of interview transcripts at any time, and the confidentiality of the interview situation. In accordance with the project guidelines, the aim was to create a warm, relaxed, permissive environment where participants would feel encouraged to express differing points of view, without pressure for consensus.

The nature of the interaction observed was closer to a focus group interview than a focus group discussion (see Boddy, 2005), with most of the interaction taking place between the moderator and individual interviewees rather than among the interviewees. Consequently, the analysis in this article focuses more on the individual experiences of interviewees than on interactions within the group. Regardless of this emphasis on individual experience, focus 
Distances and proximities of care: Analysing emotio-spatial distances in informal caring

groups inevitably produce a specific social context that has to be taken into consideration.

The social context of groups can offer a particularly fruitful environment to study experiences of informal caring, since focus group interaction helps to make the invisible aspects of caring visible, and enables connections to be made between carers' individual experiences and the group's shared experiences. Focus groups also have the potential to challenge dominant beliefs about sensitive topics such as caring, and to provide interviewees with space for reflexivity on such issues (Pini, 2002). At its best, discussing individual experiences in a focus group situation might lead interviewees to 'open up' and share insights that would not be available from individual interviews or other data sources. However, there are also challenges in conducting focus group interviews: if the group reaches a strong consensus, it may be difficult for an individual interviewee to express differing opinions (Krueger \& Casey, 1988).

The focus groups were organised according to the interviewees' educational levels. There was a total of 12 interviewees: seven in the highly educated carers group (tertiary education, International Standard Classification of Education 4 or above), and five in the less educated carers group (primary or secondary education, International Standard Classification of Education 1-3). The criteria for interviewees was that they should be employed, living in the city of Jyväskylä, and have an older relative with care needs. The interviewees' pseudonyms, ages, occupations, family situations, relationships with and distances from their care partners are presented in Table 1. As the focus groups dealt with sensitive issues, biographical details that are not relevant to the analysis have been altered to protect the interviewees' anonymity.

\section{Table 1: Interviewees: basic information}


Distances and proximities of care: Analysing emotio-spatial distances in informal caring

\begin{tabular}{|c|c|c|c|c|c|c|}
\hline Pseudonym & $\begin{array}{l}\text { Age } \\
\text { group }\end{array}$ & $\begin{array}{l}\text { Primary } \\
\text { relative with } \\
\text { care needs }\end{array}$ & Occupation & $\begin{array}{l}\text { Family } \\
\text { situation }\end{array}$ & $\begin{array}{l}\text { Focus } \\
\text { group }\end{array}$ & $\begin{array}{l}\text { Distance } \\
\text { between } \\
\text { care } \\
\text { partners }\end{array}$ \\
\hline Minna & $40-49$ & Mother & Teacher & $\begin{array}{l}\text { Married } \\
\text { with } \\
\text { children }\end{array}$ & $\begin{array}{l}\text { Highly } \\
\text { ed. }\end{array}$ & Distant \\
\hline Paula & $50-59$ & $\begin{array}{l}\text { Husband } \\
\text { (previously } \\
\text { father) }\end{array}$ & $\begin{array}{l}\text { Social } \\
\text { worker }\end{array}$ & $\begin{array}{l}\text { Married } \\
\text { with } \\
\text { children }\end{array}$ & $\begin{array}{l}\text { Highly } \\
\text { ed. }\end{array}$ & $\begin{array}{l}\text { Proximate } \\
\text { (previously } \\
\text { distant) }\end{array}$ \\
\hline Päivi & $40-49$ & Mother & Manager & $\begin{array}{l}\text { Married } \\
\text { with } \\
\text { children }\end{array}$ & $\begin{array}{l}\text { Highly } \\
\text { ed. }\end{array}$ & Distant \\
\hline Raili & $50-59$ & Mother & Researcher & $\begin{array}{l}\text { No } \\
\text { spouse or } \\
\text { children }\end{array}$ & $\begin{array}{l}\text { Highly } \\
\text { ed. }\end{array}$ & Distant \\
\hline Ritva & $50-59$ & Father & Bank clerk & $\begin{array}{l}\text { Divorced } \\
\text { with } \\
\text { children }\end{array}$ & $\begin{array}{l}\text { Highly } \\
\text { ed. }\end{array}$ & Distant \\
\hline Suvi & $40-49$ & Father & Journalist & $\begin{array}{l}\text { No } \\
\text { spouse or } \\
\text { children }\end{array}$ & $\begin{array}{l}\text { Highly } \\
\text { ed. }\end{array}$ & Distant \\
\hline Venla & $20-29$ & Grandmother & $\begin{array}{l}\text { Human } \\
\text { resources } \\
\text { specialist } \\
\end{array}$ & $\begin{array}{l}\text { Married, } \\
\text { no } \\
\text { children }\end{array}$ & $\begin{array}{l}\text { Highly } \\
\text { ed. }\end{array}$ & Distant \\
\hline Aliisa & $60+$ & $\begin{array}{l}\text { Sister } \\
\text { (previously } \\
\text { mother) }\end{array}$ & Salesperson & $\begin{array}{l}\text { Divorced } \\
\text { with } \\
\text { children }\end{array}$ & $\begin{array}{l}\text { Less } \\
\text { ed. }\end{array}$ & Proximate \\
\hline Noora & $50-59$ & Mother & $\begin{array}{l}\text { Practical } \\
\text { nurse }\end{array}$ & $\begin{array}{l}\text { Married } \\
\text { with } \\
\text { children }\end{array}$ & $\begin{array}{l}\text { Less } \\
\text { ed. }\end{array}$ & Proximate \\
\hline Riikka & $50-59$ & Mother & $\begin{array}{l}\text { Psychiatric } \\
\text { nurse }\end{array}$ & $\begin{array}{l}\text { Married } \\
\text { with } \\
\text { children }\end{array}$ & $\begin{array}{l}\text { Less } \\
\text { ed. }\end{array}$ & Distant \\
\hline Saara & $40-49$ & Aunt & $\begin{array}{l}\text { Nursery } \\
\text { school } \\
\text { teacher }\end{array}$ & $\begin{array}{l}\text { Married } \\
\text { with } \\
\text { children }\end{array}$ & $\begin{array}{l}\text { Less } \\
\text { ed. }\end{array}$ & Proximate \\
\hline Saimi & $60+$ & $\begin{array}{l}\text { Daughter } \\
\text { (previously } \\
\text { mother) }\end{array}$ & Secretary & $\begin{array}{l}\text { Married } \\
\text { with } \\
\text { children }\end{array}$ & $\begin{array}{l}\text { Less } \\
\text { ed. }\end{array}$ & Proximate \\
\hline
\end{tabular}

As Anttonen and Zechner (2011) point out, middle-aged women constitute a significant proportion of carers. This was reflected in the characteristics of our interviewees: all interviewees, with one exception, were over the age of 40, and most were over 50. According 
Distances and proximities of care: Analysing emotio-spatial distances in informal caring

to Anttonen and Zechner (ibid.), for many women, becoming a carer is a fairly 'natural' development during middle age: as their children have grown up, they begin to care for their parents or other close relatives.

\section{Thematic analysis}

The data was subjected to thematic analysis, using the guidelines developed by Braun and Clarke (2006). The focus group interviews were thematic in themselves, focusing on women's views on working life, their preferences regarding different forms of care, and their views regarding the combination of work and care. After the interview transcripts had been read and reread, distance and its role in caring was noted as a recurring topic; this led to preliminary coding on the basis of interviewees' descriptions of spatial distances between home, work and place(s) of care, and of the practicalities, negotiations and emotions related to those distances. On the basis of research literature on emotional geographies of care, more precise analytical categories and research questions were then formed. After a more comprehensive empirical and theoretical understanding of the research field had been established, new coding was carried out, followed by the seeking, reviewing and naming of themes (ibid.). The focus of the analysis was on interviewees' descriptions and experiences of spatial distance in caring and the emotions embedded in the caring process, particularly in relation to the distance between care partners.

\section{Accessing emotions in interview transcripts}

'Reading' emotions from research encounters raises several concerns regarding research ethics and validity, such as the authority by which the researcher who is reading the interview transcripts is able to characterise the emotional states of the interviewees (Laurier \& Parr, 2000; 
Distances and proximities of care: Analysing emotio-spatial distances in informal caring

Bondi, 2014). Particularly when discussing a sensitive topic such as caring in a focus group, interviewees may engage in self-conscious distancing from their own subjective feelings, and may instead perform what they consider to be socially approved emotions in order to be seen as 'respectable' carers by the other interviewees (Milligan, 2005). Thus the analysis in this article is not interested in determining whether the emotions that interviewees expressed and described in the focus group were 'real' or not. Instead, the focus is on how the emotions evoked by caring were performed and articulated in the focus group encounter (see Clayton et al., 2015). Consequently, the emotions expressed and described in the focus group are understood not only as descriptions of interviewees' personal experiences, but also as reflections of the ways in which it is culturally acceptable to talk about emotions as part of caring.

\section{Caring from differing distances}

The spatial distances involved in caring differed among individual focus group participants. All of the older relatives with care needs were living in their own homes, with some receiving home-based care services. The spatial distances between care partners varied, from living in the same household to living 300 kilometres apart. In part, distance was subjectively experienced, and what was seen as a reasonable daily or weekly travelling distance or time varied somewhat among the interviewees. These differences emerged on the basis of the modes of transport available (see Joseph \& Hallman, 1998) and differences in caringscapes - e.g. whether the carers were employed full-time or part-time, whether they could alter their own work schedules, or how temporally demanding the care they provided was.

The first two sections of this analysis focus on the emotions evoked by geographically proximate caring, and the second two on distant caring. Proximate caring is defined here as 
Distances and proximities of care: Analysing emotio-spatial distances in informal caring

care partners living within a distance that can be reasonably travelled on a daily or near-daily basis (ibid.). The definition of what constitutes reasonable daily or near-daily travelling distance depended on how the interviewee described the distance between her own and her care partner's home - whether she described travelling the distance (near-)daily, weekly or less often, and how she described this travel pattern's fit with her daily, weekly or monthly schedule.

The spatial and temporal intensiveness of within-household care

Interviewees who were currently caring for a husband, sister or daughter were providing within-household care. One of these was Saimi. She was currently caring for her daughter, but in her account in the focus group, she focused more on describing her role as a carer for her recently deceased mother, to whom she had also provided within-household care. Saimi had moved with her family to Jyväskylä to live with her mother when her mother became widowed. When Saimi's family made the decision to move, her mother did not yet have any care needs, but Saimi was preparing for the future and anticipating her mother's future care needs. Saimi was the only interviewee who had changed her place of residence in order to give care. For the majority of the other interviewees, their places of residence were more static; the idea of moving closer to the care partner was rarely mentioned in the interviews, and when it was mentioned, it was seen as impossible due to work and family arrangements. During the last years of her mother's life, Saimi's everyday life had been organised and scheduled around caring for her mother:

I cooked for her, bathed her, took her to the sauna, took care of her medication, went with her to hospital, everything [...]. During the night, I went to check on her, every 
Distances and proximities of care: Analysing emotio-spatial distances in informal caring

hour or every other hour. I used to say that I slept with my shoes and clothes on. [...] For the last six months, I was really tense, on alert all the time, because I couldn't leave her.

The caringscape had been dominated by Saimi's mother having care needs that could emerge quickly and require an immediate response. Consequently, Saimi had switched from full-time to part-time work in order to care for her mother. Despite the demanding nature of this care, Saimi's account was characterised by the articulation of emotions such as gratitude. She identified strongly with her role as carer, describing herself as always having been a 'care person' and saying the decision to be a carer 'probably comes down to personality'. In her account, caring for her mother was taken for granted. It originated from Saimi's identity as a 'care person', her life history, her relationship with her mother (cf. Finch \& Mason, 1993), and the lack of participation and empathy she perceived on the part of her siblings, particularly her sister, who 'would have put her [mother] in an institution ages ago'. However, Saimi also emphasised that for her, caring had been a choice, and she could have refused if she had wanted to do so. This balancing act - between seeing caring as something they had chosen to do, and seeing it as an inevitable responsibility because of their own life history or relational dynamics with their care partner - was particularly present in the accounts of proximate carers who were responsible for heavy caring.

The accounts of the interviewees performing within-household care reveal not only the demanding nature of care and how it reshapes the relational dynamic between care partners, but also how caring reshapes the carer's experience of home. Paula described how her husband's illness had changed their division of household chores, and the emotional consequences of that change: 
Distances and proximities of care: Analysing emotio-spatial distances in informal caring

My husband feels that he can no longer be the man of the house, he feels that he is a burden, because he can no longer do the things he did before. [...] I have to do all of the everyday chores. [...] I feel anxious about summer, because the things that used to bring me joy, summer and work in the garden, do not feel like nice and empowering things any more, when you have so many burdens.

Paula's husband could no longer participate in the physical work that the maintenance of their house required, or do the chores Paula regarded as belonging to 'the man of the house'. The domestic work, which had previously been divided according to traditional gender roles, was now something that Paula had to do by herself. Adapting to the changed situation and to new gender roles regarding the division of household work had been difficult for both Paula and her husband. The situation was emotionally strenuous, as he felt he was 'a burden', and she felt anxious about the amount and nature of the work that fell to her, resulting in her not enjoying the things she had previously enjoyed at home.

\section{Interpreting the needs of the care partner in proximate care}

Two of the interviewees reported living within walking distance of their care partners. Noora's account illustrates that living in close proximity to the care partner can make the daily logistics of caring easier, but proximity can also make it difficult to detach from care, as the carer can visit the care partner at any time. Noora visited her mother often, even during her lunch hour from work, partly due to her fear that her mother would not tell her if her health had deteriorated: 
Distances and proximities of care: Analysing emotio-spatial distances in informal caring

I was having a lunch break one day and I visited her because I had this feeling that everything wasn't alright, because yesterday she had said that her stomach hurt.

During her frequent visits to her mother, Noora closely observed possible changes in her mother's health: her mother's report of a stomach ache was not 'just' a stomach ache, but for Noora was something from which she got 'this feeling that everything wasn't alright'. She also saw everyday changes around the house as reflections of changes in her mother's health. She described how the first symptom she had noticed regarding her mother's declining health was that 'she had not cooked herself a proper dinner'. She described the current situation as follows:

She just doesn't care, her illness does such damage that she doesn't... even though no one has watered the flowers, she doesn't notice it, even though those flowers have been blooming... on the windowsill for 10,15 years, still she doesn't care about them. [...] When you ask, 'should I water the flowers?' and then [her mother says] 'I don't care'... It's so hard to accept that she no longer pays attention, no longer cares.

For Noora, her mother not cooking dinner for herself, or no longer tending to the flowers, was a reflection of her advancing illness, and of how she changed as her illness progressed. Observing the changes in her mother's house, Noora could 'read between the lines' and interpret what was happening to her mother, who she felt was otherwise reluctant to tell the truth about her changing health. Both Noora and her sister lived within walking distance of their mother, but like Saimi, Noora described herself as the one who took the main responsibility for care, due to personality differences between her and her sister. Noora described herself as more empathetic than her sister, who was 'completely different, she is a 
Distances and proximities of care: Analysing emotio-spatial distances in informal caring

kind of office person and very straightforward'.

Proximate carers were often present in the everyday of caring, and thus could closely observe even the subtlest changes in the person they were caring for. As in the study by Wiles (2003), for many interviewees doing proximate caring, the demanding physical nature of care was secondary to the emotional drain of caring. Proximate carers witnessed how the people they were caring for struggled to deal with their illness. These carers also had to come to terms with the gradual loss of the care partner, while being spatially extremely close to the care partner and doing the most physically proximate forms of caring. Temporally, their everyday lives and wider caringscapes were dominated by their role as carers.

\section{The complex gendered and generational dynamics of distant caring}

The interviewees who were caring from a distance usually had smaller role in hands-on care than those who were proximate carers. Thus the tasks conducted by distant carers were temporally less constraining and physically less demanding tasks, such as keeping the care partner company by telephone or occasional visits, doing paperwork, and organising the care partner's finances. However, long distances posed their own emotional difficulties for the interviewees. With long distances and limited opportunities to visit the care partner, distant carers often felt worry regarding their care partners' condition. Even access to public care services did not necessarily ease this worry. Riikka's mother was visited by home care services three times per day. However, her mother's care needs had gradually increased, shifting Riikka's caringscape. Consequently, Riikka did not see the current level of home care services as sufficient, and this had led her to increase her role in caring. Nevertheless, she described her current feelings of worry as 'constant, round the clock'. 
Distances and proximities of care: Analysing emotio-spatial distances in informal caring

Paula described the emotional strain caused by spatial distance while she was caring for her father, who lived 200 kilometres away:

He was suicidal. At work, I had my mobile phone in my pocket, even though I shouldn't have, but somehow I felt that if he can contact me and talk, it makes things easier, and it did, and he never did anything to himself. [...] Those were difficult phone calls during the work day, and at home too, but the distance, when he is not here, and the pain, I do understand how you [other interviewees] feel, when you cannot just go to see him.

Paula's experiences reveal the blurring of caringscapes (cf. McKie et al., 2002): not only temporal and spatial boundaries, but also the emotional boundary between work and care were blurred. She described how in her job as a social worker she experienced constant feelings of 'responsibility and inadequacy' - feelings similar to those she reported experiencing in her care partnership. She also expressed the difficulty of maintaining her professional role while going through experiences similar to those of some of her clients at work.

Paula's experiences also illustrate how long distances between family members can be used to 'hide the truth', for example regarding one's health and well-being (Baldassar, 2007, 2008). For Paula, spatial distance created insecurity about her father's well-being, since the only way to be assured of his well-being was to see him in person. Distant carers put a great deal of effort into 'reading between the lines' during contact with their care partner, such as interpreting what the care partner says (or does not say) during phone calls. This insecurity can be alleviated if one has local contacts that can provide information regarding the care partner's well-being (Baldassar, 2007). However, the worry Paula felt could not be alleviated in this way: she described herself as 'the only person for him, the only one who was kin'. 
Distances and proximities of care: Analysing emotio-spatial distances in informal caring

In the interviewees' accounts, the role of gender in caring was rarely mentioned. However, complex gendered and generational dynamics particularly emerged from the accounts of the three interviewees who were or had been caring for their ageing fathers. All of these interviewees were caring from a distance, and all were in the focus group of highly educated carers. Interviewees in this focus group expressed more of the emotional complexities embedded in the care partnership - for example, if the relationship between the ageing parent and the adult child was not particularly good. Interviewees who expressed such emotional difficulties also reflected on the limits of their role as carers. Suvi described how she had 'been through a hard ethical struggle' while caring for her father, and how she had contemplated the limits of her role as carer. She expressed discomfort about her father calling her during her workday, and about her responsibility for his medical issues. Despite expressing these ambivalent emotions, Suvi continued to be a carer to her father.

Ritva described the difficult emotions she had dealt with while caring for her father, but ultimately she also agreed with another focus group interviewee, Raili, that caring for one's ageing parents is a moral responsibility:

When my mother died, we worried about father. Then he found a new spouse, got married, and then this new spouse died... It was around three years ago, and then the worry got bigger. Before, these wives had taken good care of him, done all the housework, he has never done that in his life... Then I thought about this relationship, I thought that if my mother had lived longer, it would have been very easy to care for her. I had a warm relationship with my mother, my father was always distant to all us children, so of course it is much more difficult to care and have some kind of connection with him... So it affects that way, but I do agree [with Raili] that there is a moral 
Distances and proximities of care: Analysing emotio-spatial distances in informal caring

obligation, or responsibility, or my own morality says that you have to care for your own parents, even if the relationship has not been that warm.

In Ritva's account, gendered and generational dynamics are particularly visible. She described how she had begun to worry about her father when he was left without 'feminine' care. Her father was both emotionally and spatially distant, as they lived almost 300 kilometres apart. Yet she emphasised caring for her father as a moral obligation. Interestingly, the idea of caring for one's ageing parent as a moral responsibility, regardless of relational dynamics, was articulated more strongly in the highly educated focus group, where the emotional complexities of caring were more thoroughly discussed, and where the decision to care for an ageing parent appeared to be less straightforward.

As outlined above, for distant carers, spatial distance was often a source of continuous concern regarding the well-being of their care partner. As Baldassar (2015) points out, physical separation from a care partner can evoke feelings of guilt about not being physically present to fulfil the moral obligation of caring. Consequently, 'guilty feelings' can provide a strong motivation to put significant time and energy into keeping in touch from a distance. In some interview accounts, spatial distance also functioned as a way to set limits on the amount and intensity of caring, particularly in situations where the carer did not experience their relationship with the care partner as particularly good or close. However, caring was often simultaneously seen as a moral obligation, regardless of the relational dynamics between the care partners. 
Distances and proximities of care: Analysing emotio-spatial distances in informal caring

\section{The role of gender in dividing care}

Gender was present not only in the dynamics between care partners, but also in the interviewees' descriptions of the division of caring responsibilities. In many cases, it became clear that heavy care was mainly divided among the female kin (cf. Jegermalm, 2004). The interviewees also expressed stronger disapproval if they did not see their sisters as participating in care than they did when their brothers opted out of caring. However, gender was rarely mentioned explicitly in the interviewees' accounts. This silence regarding gender differences in caring might reflect the Nordic model of gender equality, which can lead interviewees to emphasise non-gender-related rationales for (not) providing care (Leinonen, 2011). Riikka was caring for her mother from a distance together with her two brothers, while her sister, who was spatially closest to their mother, was the primary carer. Riikka described her brothers' role in caring for their mother as follows:

My brothers have just realised [...] that our mother's situation is really bad. Even though they have visited, they just do quick visits, but if I go there, I go there in the morning and stay until eight in the evening and do something all the time, and I see the situation differently. We are different kinds of people, with differing values and attitudes, and they... My other brother is really sensitive [...]. I always think if I was being too harsh, should I soften these words, I won't be too frank about mother's condition.

Riikka's account illustrates that even when they are caring from similar spatial distances, the caringscapes and roles of male and female carers can be very different. Riikka and her brothers usually visited their mother on different days, each of them once per week. Thus their 
Distances and proximities of care: Analysing emotio-spatial distances in informal caring

caringscapes were spatio-temporally similar; but she describes differences in the content of their visits, due to their 'seeing the situation differently'. Riikka excused her brothers' reduced participation in caring, and expressed the need to do the emotion management (Hochschild, 1979) of taking care of her brothers by sheltering them from the realities of their mother's condition. Even though the dynamics of caring and emotion management in her account can be seen as gendered, she addressed them not as questions related to gender, but as questions related to personalities and values (cf. Roff et al., 2007; Finch \& Mason, 1993). Riikka's account can be seen as reflecting the wider gender discourse in Finland. This discourse, paradoxically, relies on the idea that the best way of promoting gender equality is to stay silent on issues related to gender (cf. Leinonen, 2011). However, this approach often hides how gender-unequal practices are embedded in societal structures. This can lead individuals to blame themselves for practices that go against the ideal of gender equality (cf. Sihto et al., 2018).

\section{Conclusions}

The aim of this article was to analyse how emotio-spatial distances in informal caring are experienced by Finnish women who are employed and simultaneously caring for an ageing relative. The article was particularly interested in exploring how spatial distance and proximity shape informal carers' emotional responses to caring, and the kinds of emotion that spatial distance and proximity evoke in the interview accounts of informal carers. The interviewees' accounts show how spatial distance both transcends and reinforces identities (Herron \& Skinner, 2013). Proximate carers were responsible for heavy caring, and were expected to shoulder primary responsibility for caring compared with their other kin. Consequently, they faced a complicated caringscape in their everyday lives, as they had to cope with temporally 
Distances and proximities of care: Analysing emotio-spatial distances in informal caring

unpredictable and physically demanding care. Distant carers, on the other hand, were often less involved in the everyday of care, and their role in caring was more focused on its affective aspects.

The analysis in this article highlights the emotionally complex nature of caring from differing distances. This study has identified the various ways in which carers interpret even the subtlest cues regarding their care partner's well-being. For proximate carers, this means observing small changes in their care partner's household and everyday life. For distant carers, it means reading between the lines during contact with their care partner - for example, interpreting what their care partner says (or does not say) during phone calls. This reading between the lines often entails significant amounts of emotion management (Hochschild, 1979) on the carers' part: they first closely observe subtle cues in order to interpret their care partners' 'true' needs, and then they weigh up how they can and will respond to those needs. The overarching feelings of the majority of carers in this study, regardless of distance, were worry, anxiety and insecurity regarding the well-being of their care partner. It is noteworthy that all of the interviewees' care partners lived in their own homes, some with the support of home care services. This might suggest that in the everyday of care, the services offered to support 'ageing in place' in Finland are not seen as sufficient by carers, who instead are left feeling unsure of the well-being and safety of their care partners.

The second central finding of this article emphasises gendered relational dynamics, both among (potential) carers and in the care partnership, even though gender was rarely explicitly mentioned in the interviews. Regardless of distance, the interviewees rationalised their own caring role and that of other kin by using similar justifications, which were often related to individual personality traits (cf. Leinonen, 2011; Finch \& Mason, 1993) rather than gender. However, caring for an ageing parent was mainly negotiated and divided among female 
Distances and proximities of care: Analysing emotio-spatial distances in informal caring

kin. Differences also emerged on the basis of the care partner's gender: in the interviewees' accounts, caring for one's ageing mother was seen as 'natural', whereas relationships between adult daughters and ageing fathers were more complex and led interviewees to reflect on the limits of their caring role. The interviewees who had been or were currently caring for their fathers were all caring from a distance.

Thirdly, this article highlights the ways emotions enter and shape caringscapes. Even when the spatio-temporal conditions remain the same, the emotional dynamics of the care partnership can alter the experience of the caringscape and the emotions attached to it. This was particularly visible in the accounts of distant carers: distance could be a source of agony, but it could also function as a way to set limits on the amount and intensity of caring in an emotionally difficult situation, if the carer did not experience their relationship with the care partner as particularly good. Thus, compared with proximate carers, those who were caring from a distance often had more opportunities to set limits on their role as carers and to alter the role of care in their caringscape, whereas proximate carers more often faced difficulties detaching from care, and more often had to (re)negotiate their working arrangements.

This article offers some important insights into the complex interplay of spatial distances and emotional dynamics in caring. Spatial distance is not just an objective measure, but is always subjectively experienced: emotions shape the experience of spatial distance in caring, and vice versa. Therefore, it is important to include emotions in the analysis of the everyday spatio-temporal realities of caring. As 'ageing in place' and informal care by family members and other kin are strongly promoted in public policy, it is crucial to pay attention to how care is carried out in practice - who is doing the caring, and what it entails. Previous studies (e.g. Jolanki et al., 2013; Kauppinen \& Jolanki, 2012) have highlighted the challenges and distress experienced by working carers, and it is therefore important to understand the 
Distances and proximities of care: Analysing emotio-spatial distances in informal caring

experiences of working carers more deeply, in order to facilitate the combination of work with care. Focusing on the emotio-spatial aspects of care offers a rarely used yet important lens for understanding the negotiations and conditions of care (Herron \& Skinner, 2013).

A central limitation of this study is that it is based on data from small focus groups. As methodological literature (e.g. Krueger \& Casey, 1988) points out, focus groups constitute social settings where the performance of 'respectability' is more present than, for example, in individual interviews or written narratives. Thus analyses based on different kinds of data are crucial to enhance our understanding of the interplay of gender, caring and emotional geographies, particularly with regard to difficult or negative emotions related to caring. Future research might consider the relational dynamics between care partners and the role of gender in care partnerships.

\section{References}

Ahmed, S. (2004). The Cultural Politics of Emotion. London: Routledge.

Anttonen, A. \& Zechner, M. (2011). Theorising care and care work. In B. Pfau-Effinger \& T. Rostgaard (Eds), Care Between Work and Welfare in European Societies (pp. 15-34). London: Palgrave Macmillan.

Baldassar, L. (2007). Transnational families and the provision of moral and emotional support: The relationship between truth and distance. Identities: Global Studies in Culture and Power, 14(4), 385-409.

Baldassar, L. (2008). Missing kin and longing to be together: Emotions and the construction of co-presence in transnational relationships. Journal of Intercultural Studies, 29(3), $247-266$. 
Distances and proximities of care: Analysing emotio-spatial distances in informal caring

Baldassar, L. (2015). Guilty feelings and the guilt trip: Emotions and motivation in migration and transnational caregiving. Emotion, Space and Society, 16, 81-89.

Boddy, C. (2005). A rose by any other name may smell as sweet but 'group discussion' is not another name for a focus group nor should it be. Qualitative Market Research: An International Journal, 8(3), 248-255.

Bondi, L. (2008). On the relational dynamics of caring: A psychotherapeutic approach to emotional and power dimensions of women's care work. Gender, Place and Culture, 15(3), 249-265.

Bondi, L. (2014). Understanding feelings: Engaging with unconscious communication and embodied knowledge. Emotion, Space and Society, 10, 44-54.

Bowlby, S., McKie, L., Gregory, S. \& MacPherson, I. (2010). Interdependency and Care Over the Lifecourse. London: Routledge.

Brandt, M., Haberkern, K. \& Szydlik, M. (2009). Intergenerational help and care in Europe. European Sociological Review, 25, 585-601.

Braun, V. \& Clarke, V. (2006). Using thematic analysis in psychology. Qualitative Research in Psychology, 3(2), 77-101.

Bryden, C. (2005). Dancing with Dementia: My Story of Living Positively with Dementia. London: Jessica Kingsley Publishers.

Clayton, J., Donovan, C. \& Merchant, J. (2015). Emotions of austerity: Care and commitment in public service delivery in the north east of England. Emotion, Space and Society, 14, $24-32$.

Davidson, J. \& Milligan, C. (2004). Embodying emotion sensing space: Introducing emotional geographies. Social \& Cultural Geography, 5(4), 523-532. 
Distances and proximities of care: Analysing emotio-spatial distances in informal caring

Evans, R. \& Thomas, F. (2009). Emotional interactions and an ethics of care: Caring relations in families affected by HIV and AIDS. Emotion, Space and Society, 2(2), 111-119.

Finch, J. \& Mason, J. (1993). Negotiating Family Responsibilities. London: Routledge.

Frericks, P., Jensen, P. H. \& Pfau-Effinger, B. (2014). Social rights and employment rights related to family care: Family care regimes in Europe. Journal of Aging Studies, 29(1), $66-77$.

Graham, H. (1983). Caring: A labour of love. In J. Finch \& D. Groves (Eds), A Labour of Love: Women, Work and Caring (pp. 13-30). London: Routledge.

Hequembourg, A. \& Brallier, S. (2005). Gendered stories of parental caregiving among siblings. Journal of Aging Studies, 19(1), 53-71.

Herron, R. V. \& Skinner, M. W. (2013). The emotional overlay: Older person and carer perspectives on negotiating aging and care in rural Ontario. Social Science \& Medicine, 91, 186-193.

Hillcoat-Nallétamby, S. \& Phillips, J. E. (2011). Sociological ambivalence revisited. Sociology, 45(2), 202-217.

Hochschild, A. R. (1979). Emotion work, feeling rules, and social structure. American Journal of Sociology, 85(3), 551-575.

Jegermalm, M. (2004). Informal care and support for carers in Sweden: Patterns of service receipt among informal caregivers and care recipients. European Journal of Social Work, 7(1), 7-24.

Jolanki, O. (2015). To work or to care? Working women's decision-making. Community, Work \& Family, 18(3), 268-283.

Jolanki, O., Szebehely, M. \& Kauppinen, K. (2013). Family rediscovered? Working carers of older people in Finland and Sweden. In T. Kröger \& S. Yeandle (Eds), Combining Paid 
Distances and proximities of care: Analysing emotio-spatial distances in informal caring

Work and Family Care (pp. 53-70). Bristol: Policy Press.

Joseph, A. E. \& Hallman, B. C. (1998). Over the hill and far away: Distance as a barrier to the provision of assistance to elderly relatives. Social Science \& Medicine, 46(6), 631-639.

Kauppinen, K. \& Jolanki, O. (2012). Työn sekä omais- ja läheishoivan yhdistäminen - työssä jatkamisajatukset. In M. Perkiö-Mäkelä \& T. Kauppinen (Eds), Työ, terveys ja työssä jatkamisajatukset (pp. 133-156). Helsinki: Työterveyslaitos.

Kröger, T. \& Leinonen, A. (2012). Transformation by stealth: The retargeting of home care services in Finland. Health and Social Care in the Community, 20(3), 319-327.

Krueger, R. A. \& Casey, M. A. (1988). Focus Groups: A Practical Guide for Applied Research. London: Sage.

Laurier, E. \& Parr, H. (2000). Disability, geography and ethics: Emotions and interviewing in health and disability research. Philosophy \& Geography, 3(1), 98-102,

Leinonen, A. (2011). Adult children and parental care-giving: Making sense of participation patterns among siblings. Ageing and Society, 31(2), 308-327.

Lynch, K. (2007). Love labour as a distinct and non-commodifiable form of care labour. Sociological Review, 55(3), 550-570.

McKie, L., Gregory, S. \& Bowlby, S. (2002). Shadow times: The temporal and spatial frameworks and experiences of caring and working. Sociology, 36(4), 897-924.

Meagher, G. \& Szebehely, M. (Eds) (2013). Marketisation in Nordic eldercare: A research report on legislation, oversight, extent and consequences. Stockholm: Stockholm University.

Milligan, C. (2001). Geographies of Care: Space and the Voluntary Sector. Aldershot: Ashgate.

Milligan, C. (2005). From home to 'home': Situating emotions within the caregiving 
Distances and proximities of care: Analysing emotio-spatial distances in informal caring

experience. Environment and Planning A, 37(12), 2105-2120.

Milligan, C. \& Wiles, J. (2010). Landscapes of care. Progress in Human Geography, 34(6), $736-754$.

Ministry of the Environment (2013). Housing Development Program for Older Population for 2013-2017. Helsinki: Ministry of the Environment.

Phillips, J. E. \& Bernard, M. (2010). Work and care: Blurring the boundaries of space, place, time, and distance. In A. Martin-Matthews \& J. E. Phillips (Eds), Aging and Caring at the Intersection of Work and Home Life: Blurring the Boundaries (pp. 85-105). New York: Psychology Press.

Pini, B. (2002). Focus groups, feminist research and farm women: Opportunities for empowerment in rural social research. Journal of Rural Studies, 18(3), 339-351.

Roff, L. L., Martin, S. S., Jennings, L. K., Parker, M. W. \& Harmon, D. K. (2007) Long distance parental caregivers' experiences with siblings: A qualitative study. Qualitative Social Work, 6(3), 315-334.

Sihto, T., Lahti, A., Elmgren, H. \& Jurva, R. (2018). Naisvalitus ja parisuhteen epätasa-arvot. In: P. Eerola \& H. Pirskanen (Eds), Perhe ja tunteet (pp. 279-299). Helsinki: Gaudeamus.

Wiles, J. (2003). Daily geographies of caregivers: Mobility, routine, scale. Social Science \& Medicine, 57(7), 1307-1325. 